\title{
State Capacity and Leadership in ASEAN and the EU
}

\subsection{INTRODUCTION}

This chapter examines state capacity as an explanatory factor in order to reconceptualise political leadership in a regional context. By state capacity, this book means the willingness of member states to utilise their tangible, intangible, and institutional power resources in terms of governance capacity to lead regional initiatives. This involves the state's utilisation of tangible, intangible, and institutional power resources in order for a state or a combination of states to be able to effectively lead regional initiatives. This book argues that tangible resources such as economic advantage, size of a country, administrative machinery, and military capabilities, as well as intangible resources such as foreign policy, political system, and culture provide advantages for a particular state to play leadership roles in regional community-building efforts. Furthermore, institutional power resources can also provide more leverage for a state to exert influence in the development of regional community-building. Therefore, this book argues that state capacity is crucial in the provision of regional political leadership as it helps to sustain the benefits of regional integration and to continuously build and strengthen regional community-building through policy implementation and policy continuity. Conversely, the lack of such capacity can impede the progress of regional community-building efforts.

This chapter is organised into three sections. The first section surveys the scholarly literature on state capacity, which includes tangible, intangible, and institutional power resources, and its importance for exercising

(C) The Author(s) 2019

S. D. Mohamed Pero, Leadership in Regional Community-Building, https://doi.org/10.1007/978-981-13-7976-5_4 
leadership role. The second section examines the degree to which state capacity (or the lack thereof) offers advantages or challenges for a particular ASEAN member state to provide leadership and how this affects the development of the ASEAN Community. The final section assesses the relationship between state capacity and leadership in the EU context, and the degree to which state capacity has influenced its member states' behaviour to exert more influence in the EU.

\subsection{State Capacity and Regional Community-Building}

The issues of state capacity and the related ideas about state and power on one hand, and leadership on the other, have generated considerable debate among scholars who argue that state capacity makes an important contribution in the provision of leadership in a regional context (e.g. Mattli 1999a; Zwartjes et al. 2012). Scholars such as Fawcett $(2005,2013)$ and Zwartjes et al. (2012) explain the importance of state capacity for a particular state to be considered as, and to act in the manner of, a leader. For Fawcett (2005), regional community-building is about accomplishing regional integration objectives. For potential leaders to be able to make decisions, provide solutions to overcome deadlocks, or to act as the driver for other member states, access to state resources is advantageous.

Scholars such as Anderson et al. (2005), Genna and Hiroi (2007), and Hendrix (2010) argue that material or tangible resources are important assets underpinning claims for leadership in a regional context. These material resources include economic strength, population size, territory, military capabilities, political stability, and administrative capacity. A state with a large economy will be able to lead smaller states by bearing the cost of regional integration disproportionately, a role that Mattli (1999a, p. 16) describes as the 'regional paymaster' - a role that has been performed by Germany in the European context, for example. Additionally, a state's economic strength acts as an advantage for the state to be a core provider of collective goods to other member states, such as through the creation of regional institutions to help states cooperate with each other (Genna and Hiroi 2007, p. 54).

Administrative capacity refers to the strength of the central administration in any given state, that is, its skill in running the state and in engaging in bilateral and multilateral negotiations (Thorhallsson 2006, p. 19). The number of civil servants, or, in the external context, the size of diplomatic 
corps, is one indicator of this capacity. The human capital of the bureaucracy, which includes the practical skills of the administrative staff required to manage the states efficiently, is also vital (Thorhallsson 2006, p. 19). The presence of administrative capacity with well-trained bureaucrats is advantageous for a state to exercise leadership in a regional body, especially within the areas of policymaking and the implementation process (Archer and Nugent 2006, p. 3). For example, the commitment and the willingness of the larger states in Europe, such as France and Germany, to utilise their administrative capacity have enabled them to promote new policies and ensure the implementation of their proposed agenda (Tallberg 2008).

Additionally, the size of the country, as one interviewee mentioned, 'does matter in regional contexts [ASEAN]' (Emmers 2011). In this regard, Emmers (2011) argued that 'being the largest country obviously has a lot of influence'. However, many scholars have also recognised the leadership roles of small states in region-building (Acharya 2008; Bunse 2009; Lee 2006; Nugent 2010). For instance, Singapore-the smallest state in ASEAN—champions ASEAN's economic integration through various economic policies and initiatives to help reduce the gaps among ASEAN member states (Severino 2006, p. 29). Thus, while the size of the state might be important to be perceived as the 'natural leader', such as in the case of Indonesia in ASEAN, the correlation between a state's size and the extent to which it can play a leadership role in region-building is difficult to establish. This is because the size of a state is not a sufficient condition for leadership. Rather, leadership requires more elements of state capacity, such as strong administrative capacity with quality bureaucrats and technocrats.

In addition, intangible resources such as culture, political values, and foreign policy must also be taken into consideration as a resource of state capacity in a regional organisational context. The attraction of these recourses can help states achieve their goals without tangible coercion and inducement, or as what has been coined by Nye $(2004,2009)$ as 'soft power'. In a regional organisational context, the manner in which a state acts to achieve its foreign policy goals, to a large extent, impacts substantially on its capacity to be a leader in the development of regional integration projects. For example, Indonesia's proactive foreign policy in the promotion of human rights and democracy, as a reflection of its post-Suharto political values, has increased its leadership capacity as the leader of ASEAN (Emmers 2014; Laksamana 2011). 
Institutional power resources can also be translated as resources for state capacity to facilitate leadership roles in regional organisations such as ASEAN and the EU (Schild 2010; Tallberg 2008). The Chairmanship of the ASEAN Summit is the highest institutional power resource for ASEAN member states to exert more influence within ASEAN, as stipulated in Article 7(2.b) of the ASEAN Charter. For EU member states, the EU decision-making bodies such the Commission, the Council of Ministers, the European Parliament, and the rotating presidency within the Council of the EU can also be utilised to exert influence in agenda-setting and policymaking within the EU.

In a comparative regionalism perspective, Mattli's (1999a) work is important in order to understand the conditions that are conducive to the success and failure of economic integration schemes. Mattli (1999a, b) presents the existence of 'an undisputed leader' such as Germany in Europe, the US in North America Free Trade Agreement (NAFTA), and ASEAN in Asia-Pacific regionalism. The undisputed leader who is willing to lead and able to accommodate demands for functional cooperation is a supply condition for the development of regional integration. In Mattli's examination, the presence of an undisputed leader who is willing to lead a regional integration project is a supply condition. This is particularly so when referring to hegemonic states such as Germany in Europe and US in the context of NAFTA (Mattli 1999a, p. 16).

Webber (2010), however, suggests that an undisputed leader does not necessarily come from a hegemonic country. Instead, leadership may come from the 'coalition of big regional powers' (Webber 2010, p. 326). Webber gives an example of how the Franco-German alliance provided a more conducive environment for regional integration than the existence of a single state. Indeed, the importance of Franco-German alliance has been described by scholars such as Cole (2008) and Hayward (2008) as an axis, an engine, a motor, or a couple, driving and facilitating European integration.

Drawing on Mattli's (1999a, b) and Webber's (2010) contributions to the examination of state leadership in region-building, this chapter advances two key arguments to further understand the relationship between state capacity and leadership in regional integration projects. These arguments serve as the backbone of the chapter both theoretically and empirically so as to conduct comparative regional study of regional leadership.

First, the chapter argues that only when there is a group of states willing and able to play leadership roles in the formation or maintenance of regional integration projects, can these projects be established 
or maintained. The necessity of such groups to lead regional integration projects was a common theme in the interviews and document analysis conducted. These sources emphasised the relationship of state capacity and the function of leadership in regional integration projects, especially in the ASEAN case.

Second, the core states, referred to as core or leader states-either regional or global hegemons-(Fawcett 2015, p. 39), which actively promote ideas, strategies, and initiatives to process of integration, do not necessarily come from the 'coalition of big powers' (Webber 2010, p. 326). Rather, it can be a coalition of big and smaller powers in the region that are willing and able to play leadership roles. These coalitions can shift, depending on the issue at hand, as seen in the EU. It can also be in the form of sectoral leadership, where a particular state champions the promotion and implementation of a specific issue in regional communitybuilding, as seen in ASEAN, with Indonesia championing regional integration on political and security issues and Singapore promoting and facilitating economic integration in ASEAN. Therefore, it is the behaviour of states that are able and willing to lead that will be examined in this chapter. It will assess the strategies (dependent on the existing state capacity) utilised by ASEAN and the EU member states in order to sustain the benefits of regional community-building.

\subsection{The ASEAN Experience}

The complex and nuance nature of political leadership in ASEAN, especially on its role and function, has attracted scholarly attention (Anwar 2006; Emmers 2014; Rattanasevee 2014). The focus of such scholarly works has been on the role of Indonesia as the de facto leader of ASEAN, and the problem of leadership vacuum within ASEAN while Indonesia was preoccupied with domestic economic and political turmoil in the late 1990s. The leadership vacuum has weakened and stalled ASEAN, as the Association suffered and is still suffering from lack of direction and progress in regional commitment (e.g. Emmers 2014; Rattanasevee 2014, p. 116).

Many have agreed that because of the 'leadership vacuum', other forms of leadership exist in ASEAN. There is sectoral leadership (issue-based leadership) (Anwar 2006; Rattanasevee 2014; Severino 2004, 2006) and coalition leadership (Anwar 2006; Severino 2004, 2006). Sectoral leadership refers to leadership exhibited through areas or sectors of competence, 
depending on which state is in a better position to take the lead at the time (Rattanasevee 2014, p. 118). In general, Indonesia champions regional cooperation on security and political issues. Singapore and Thailand, and to some extent Malaysia, are more prominent in economic matters, promoting and brokering economic initiatives deemed necessary in advancing the progress of economic integration in Southeast Asia (Dent 2006; Severino 2006). The Philippines tends to focus more on sociocultural cooperation (Severino 2006, pp. 27-32). Meanwhile, coalition leadership refers to leadership formed among a group of states that share a common vision and wish to play a strategic role in the region, as has been demonstrated by Singapore and Thailand (Severino 2006, pp. 27-32). This is similar to the case of the EU where France and Germany clearly are coalition leaders and jointly exercise leadership in the EU.

Anwar (1997, p. 33) argues that the existing form of leadership in ASEAN is due to the embedded 'ASEAN Way', whereby one of its core principles is equality among all member states. It prevents any single member from having undue influence on the organisation or in pursuing its own interests against the others' interests (Anwar 1997, p. 33). Drawing and extending from Anwar, this book argues that the existing forms of leadership in ASEAN could also be seen as a reflection of the state capacity, which a particular state enjoys. This explains, for instance, the fact that Singapore, which has one of the strongest economies among ASEAN states, has been the key leader in promoting and facilitating ASEAN economic integration. Furthermore, the book argues that existing sectoral and coalition leaderships can be understood as strategies of a state or a group of states to exercise leadership roles, especially in gaining and sustaining the benefits of the ASEAN regional community by focusing on either issue-based leadership (sectoral leadership) or collaborative leadership (coalition leadership) without necessarily jeopardising the ASEAN equality norm.

\subsubsection{Sectoral Leadership in ASEAN: Indonesia}

'Those were the golden years for Southeast Asia', claimed the then Singapore's Prime Minister Lee Kuan Yew (2000, p. 319) in his memoir, recognising the leadership role of Indonesia in ASEAN in the early 1900s. Indonesia, as the largest country in Southeast Asia, was (and still is) regarded as a de facto leader in ASEAN, especially in driving, facilitating, and determining the sets of norms and rules that are acceptable and unac- 
ceptable to be embedded in regional politico-security integration. Its role in steering ASEAN could be seen from the 1970s to the 1990s, particularly in building solidarity among ASEAN member states through mutual trust and reconciliation, in leading ASEAN diplomacy during the Cambodian peace negotiations and creating the conditions for stronger economic growth in all ASEAN states.

In exercising its leadership role, especially during the first three decades of ASEAN, Indonesia focused on two areas where it had the capacity to lead-political and security matters-with less focus on matters of economic and functional cooperation. President Suharto acknowledged this in 1969 when he stated that ' $[\mathrm{w}] \mathrm{e}$ shall only be able to play an effective role if we ourselves are possessed of a great national vitality' (cited in Leifer 1989, p. 181). This explains why Indonesia was able and willing to play a leadership role under Suharto's New Order foreign policy, and why it focused on the political and security spheres in providing a leadership role in ASEAN.

Prior to the formation of ASEAN, Thailand invited Indonesia, the largest country in the region, to join the Association of Southeast Asia (ASA) as an attempt to rejuvenate the ASA (Berita Harian 1966; The Straits Times 1966). Thanat Khoman stated, in an interview, that '[w]e (ASA) approached Indonesia and asked it to join in a new organisation, an enlarged ASA' (cited in Mcbeth 1977, p. 14). Indonesia, however, decided to reject the invitation (Berita Harian 1966). According to Chaidir Anwar Sani, an assistant to Indonesia's then foreign minister Adam Malik, and a member of the official delegation to Bangkok in 1967, one of the reasons for its rejection was because of its size (Anwar 1994, p. 50). As the largest and the most populous state in the region, ${ }^{1}$ Indonesia, according to Chaidir Anwar Sani, was too proud to become a junior member of the Association (Anwar 1994, p. 50). What Indonesia did instead was propose a new regional association in which all members would have equal status and rights, to be known as Southeast Asian Association for Regional Co-operation (SEAARC) in 1966 (Anwar 1994, p. 50; Murphy 2002, p. 320). It was a modest proposal, without a clearly formulated conceptual framework, as Indonesian officials feared that an ambitious proposal would be seen as an indication of Indonesian hegemony (Anwar 1994, p. 51). Indonesia's inclination to propose a new regional organisation illustrated Indonesia's ability and willingness to participate in and lead the new regional organisation in the 1960s.

${ }^{1}$ Indonesia at that time represented more than 65 per cent of the combined ASEAN population. 
Nevertheless, not all states in the region appreciated Indonesia's move. Malaysia, especially its former Prime Minister Tunku Abdul Rahman, still had bitter memories of Jakarta's 'konfrontasi policy' and was sceptical of Indonesia's intention and commitment to the new organisation (Phanit 1980 , p. 35). Furthermore, as a founder of ASA, Tunku Abdul Rahman was reluctant to see the ASA scrapped for a new regional body in order to incorporate Indonesia (The Straits Times 1967b). Singapore's major concern was with the broad framework of the proposal, as it did not offer any 'concrete benefits' for the members. It thus felt that meetings to further discuss this endeavour 'would be wasting our time' (Phanit 1980, p. 35). The Philippines opposed the SEAARC, especially relating to the extent to which great power influences should be excluded, and how that might be accomplished. ${ }^{2}$ Thailand, however, was the only country that supported Indonesia without any major reservations for two main reasons. First, Thailand felt vulnerable to the conflicts of its neighbours: Vietnam, Laos, and Cambodia (Severino 2006, p. 2). Second, Thailand realised that it should never become too dependent on any single large power-especially the US, as a result of the growing military relationships between Thailand and the US from early 1960 up to 1970 (Phanit 1980, p. 34). Therefore, regional cooperation was seen by Thailand as a potential alternative to reduce its dependence on any single major power.

Despite the lack of interest on the part of Malaysia and Singapore, and the Philippines' objections, they were unable to simply ignore the proposal for a new organisation from Indonesia-the largest country in the region. Indeed, Thanat Khoman argued that the failure of ASA was mainly because of the absence of Indonesia in the Association (Murphy 2002, p. 324). Thanat believed that the most important issue in the search for a regional organisation in Southeast Asia was to secure Indonesian participation in the new organisation (Murphy 2002, p. 317). Likewise, in contrast to Tunku Abdul Rahman, Abdul Razak, the then foreign minister of Malaysia, shared Thanat's view that the key to a successful regional organisation was the participation of the biggest state in the region-Indonesia (Murphy 2002, p. 326). Singapore, as a newly independent city-state, decided to support the new proposal for a regional organisation as a strategy to seek 'the understanding and support of its neighbours in enhancing

\footnotetext{
${ }^{2}$ In this sense, the Philippines believed that the US presence was key to containing China. Indonesia, in contrast, thought that the US presence only antagonised China and raised the spectre of conflict in the region (Murphy 2002, p. 321).
} 
the stability and security in the region' (Lee 2000, p. 369). The Philippines, although not happy with the proposal, realised that it had little choice but to support the SEAARC, or be left out (Murphy 2002, p. 337).

Thanat and Ramos, the then foreign minister of the Philippines, however, objected to the acronym SEAARC because it sounded too much like 'shark', and thus might give people very old ideas about the proposed regional association (Anwar 1994, p. 51; Murphy 2002, p. 343). Malik proposed the name ASEAN for the new regional association (The Straits Times 1967a), which was chosen as a gesture to Malaysia since it sounded similar to ASA and was viewed favourably by the leaders, because its pronunciation resembled 'Asian' (Murphy 2002, p. 343). ASEAN was finally established on 8 August 1967.

The first decade of ASEAN was a time when the focus of its leaders was on building regional solidarity through socialisation and building trust among them. It was a period when the leaders got to know each other and to learn how to cooperate with one another (Wanandi 2008). 'It took ten years before we developed cohesion and direction in our activities, time for the leaders and officials to get to know and take the measure of each other', said Lee Kuan Yew (2000, p. 369). To cement the intra-ASEAN relationship, Indonesia made several confidence-building gestures through closer regional cooperation in areas of mutual concern, such as the threat of communism and the reduction of great power competition in the region (Antolik 1990, p. 20). Indonesia focused on attempts to control the communist threat in Borneo and to strengthen its relationship with Malaysia (Antolik 1990, p. 20). In March 1968, Malik assured Lee Kuan Yew that Indonesia was ready to protect Singapore against the communists after the British withdrew in 1971, stating that '[w]e shall protect them $(200$ million of ASEAN) even if the threat comes from Genghis Khan' (Adam Malik cited in Lee Kuan Yew 2000, p. 297). This helped to improve relations and mitigate suspicions among Indonesia, Malaysia, and Singapore.

Indonesian leadership was sustained in the second and third decades of ASEAN, especially in the peace negotiation processes aimed at finding a political solution to the Vietnam-Cambodia conflict following Vietnam's invasion of Cambodia in $1978 .{ }^{3}$ From 1982 to the signing of the Final Act of the Paris International Conference on Cambodia on 23 October 1993,

\footnotetext{
${ }^{3}$ The conflict started in 1978 after Vietnam invaded Democratic Kampuchea (Cambodia). The invasion was intended to stop cross-border attacks by the Khmer Rouge, but also actively ended the Pol Pot regime. The Pol Pot regime was ousted and was replaced by Vietnam, with a puppet government headed by Heng Samrin (Murphy 2002).
} 
Indonesia played a central role in the peace negotiations under the leadership of its Minister of Foreign Affairs Mochtar Kusumaatmadja, and his successor Ali Alatas. In November 1985, Indonesia offered to host an informal 'cocktail party' for all warring Cambodian factions. Consequently, on 29 July 1987, Mochtar Kusumaatmadja and Vietnamese Foreign Minister Nguyen Co Tach convened an informal meeting in which they agreed that all Cambodian factions should be brought together to find a peaceful solution. This led to the First and Second Jakarta Informal Meetings on Cambodia in July 1988 and February 1989, respectively. Indonesia, co-chairing with France, convened the Paris International Conference on Cambodia, which was held in two sessions: the first from 30 July to 30 August 1989, and the second from 21 to 23 October 1991 (United Nations 1991). Although the conference did not have any substantial outcome (Caballero-Anthony 2005), it displayed Indonesia's capacity to coordinate the peace negotiation process.

Despite Indonesia's effective leadership role in the political and security areas, many scholars have blamed Indonesia for the relatively low level of economic integration in ASEAN (e.g. Chowdhury 2007). Indonesia's limited national capacity, such as a low level of economic growth, and the past inability of Suharto and his top ministers to project the ideas of economic integration hindered Indonesia's leadership on economic integration since the early days of ASEAN, even if 'Indonesia wanted to do so' (Anwar 1994, p. 49). Lee Kuan Yew (2000, p. 371) wrote in his memoir that Suharto 'spoke only Bahasa Indonesia and could not engage in a free exchange in English. He preferred bilateral meetings. Then he would speak with animation and vigour in Bahasa Indonesia and, in the late 1980s use English words and phrases to get his ideas across'. Lee Kuan Yew $(2000$, p. 329) further added that '[ $t$ ] he Dutch had not left many trained Indonesian administrators and professionals; there were few institutions that could carry the country forward, and three and half years of Japanese occupation had wrecked whatever administration there was'. To date, the Indonesian bureaucracy is still staffed by incompetent civil servants and at the same time suffers from corruption (Parlina 2015; Prasojo 2012). The problems of Indonesia's bureaucracy and bureaucrats, according to the former President of Indonesia Susilo Bambang Yudhoyono (cited in Lukito 2012), 'provide obstacles to Indonesian economic growth'. (cited in Lukito 2012). The lack of state capacity in this regard has prevented Indonesia from playing a leadership role in the economic sphere, forcing it to focus on its areas of strength-political and security areas. 
This explains why ASEAN, under Indonesia's leadership, was successful in finding regional resilience, and why economic cooperation was not on ASEAN's main agenda in the first ten years following its formation (Smith 1999). Certainly, some progress was made-a number of committees dealing, for example, with food and agriculture, communications, tourism, commerce, and industry were set up-but there was no concrete progress in regional economic cooperation (see Appendix C: Issues Areas of Cooperation in Two Decades of ASEAN). Due to its economic disadvantages, Indonesia opted to be a 'non-decision' leader in matters concerning economic integration. Indonesia took the position of either not doing anything or purposely delaying the economic integration process (Narjoko 2014). For example, because of Indonesia's economic weaknesses, the government long resisted proposals for intra-ASEAN trade liberalisation, as it was perceived that this would disadvantage Indonesia. The absence of any substantial moves towards trade liberalisation until the early 1990s is evidence of this (Anwar 2006, p. 26).

In a bid to remain the leader in ASEAN after its leadership capacity was eroded following the 1997 financial crisis, Indonesia has, since 2003, focused on the promotion of democratisation and human rights. Hassan Wirajuda, the then Indonesian foreign minister, provided impetus by introducing the concept of shaping and sharing norms in an attempt to promote the importance of ASEAN for having common understanding of democratisation and human rights (Djani 2009, p. 139). As Djani (2009, p. 139) argues, 'it would be hard to build an ASEAN Community without a single set of rules that represent ASEAN norms/values and principles within legal framework acceptable to all' (Djani 2009, p. 139). According to Hernandez (2011), 'we have to credit Indonesians for being creative and imaginative' as 'they proposed the APSC and put all the political development, shaping and sharing norms, conflict prevention, conflict resolution, post-conflict peace building, and then institution building' (Interview).

A number of interviewees and scholars (e.g. Rattanasevee 2014) shared the same opinion of Indonesia's capacity and capability to push for a more democratic ASEAN and to increase human rights in ASEAN. Emmers (2015), during an interview for this project, stated that 'Indonesia has played a very important role in the democratisation process in the region, and Indonesia, as the largest country obviously has a lot of influence'. Emmers also referred to Indonesia's ability to exert influence in the promotion of the normative values in ASEAN when he recalled that "five to 
ten years ago, you would not have seen words like democracy, human rights and good governance being mentioned in ASEAN documents. But Indonesia, I think has a very clear idea of what it would like ASEAN to do, ... to promote a form of governance which is similar to what it is nowthe parliamentary democracy - that focuses on the protection of human rights and so on'.

\subsubsection{Sectoral Leadership: Singapore}

According to Severino (2006, p. 29), Singapore, the smallest country in the Southeast Asian region, is ASEAN's leader in the development of regional economic integration. Singapore saw participation in ASEAN as a necessity, due to its small size, economic dependency, and lack of natural resources (Dent 2006; Severino 2006, p. 30). According to Singapore's then Foreign Minister S. Jayakumar, it was due to its small size that Singapore gave high importance to ASEAN, because whatever happened in the region affected Singapore (cited in Severino 2006, p. 30). The prime minister, according to S. Jayakumar, made good use of the state's capacity before each ASEAN Summit by holding brainstorming sessions with officials, primarily from the ministries of foreign affairs and trade and industry, on ways of making the ASEAN Summit a success and further advancing ASEAN interests (Severino 2006, p. 30). Indeed, the economic advantage in terms of gross domestic product (GDP) that Singapore enjoys has increased its capacity to exert influence in an area that has been relatively neglected in ASEAN, that is, economic integration.

Since 1970, Singapore has taken a greater interest in the development of ASEAN economic cooperation. Singapore lobbied for the establishment of the ASEAN Free Trade Area (AFTA) as early as 1970s (Rau 1981, p. 108). This proposal was, however, rejected by other ASEAN member states due to their 'inward-looking' economies. Singapore, at this stage, had to compromise with other ASEAN colleagues who preferred 'inwardlooking' economies, which focused on meeting the needs of their rural population (Rau 1981, p. 105). Nonetheless, with Singapore continuing to advance an agenda for closer economic integration, the ASEAN Preferential Trading Agreement (PTA) was signed at the 2nd ASEAN Summit in 1977 in Kuala Lumpur, whereby each ASEAN country agreed to tariff reductions on imports tariff from other member countries.

It was 20 years later, when Singapore hosted the 4th ASEAN Summit, that the AFTA came into force. Since then, almost all major economic 
initiatives in ASEAN have come from Singapore, through utilising its state capacity. Singapore's strategic relationship with major powers such as the US, China, and the EU, and its close trade relationship with major economies such as Australia, China, Japan, and Korea through Free Trade Agreements (FTA), encouraged it to initiate the ASEAN-India Summit, the Forum for East Asia-Latin America Cooperation, and a proposal for a free trade area between ASEAN and China. The close relationship between Singapore and France, as well as Germany, also led to the establishment of Asia-Europe Meeting (ASEM) (Camroux 2006, p. 5; Robles 2007, p. 1). Furthermore, as Singapore has been playing an increasingly active role in multilateral groupings such as ASEM, its Foreign Affairs Ministry has recruited better-qualified officials to join it ranks to enhance the capacity of its officials. The candidates, among other requirements, must have at least five-years of working experience, be intellectually able and resourceful, and have management skills and integrity (Mien 1996). Indeed, based on a survey conducted in 2012, entitled 'Bureaucracy: Asia's Best and Worst', Singapore's civil service ranked top among 12 Asian economies, being least encumbered by red tape and the concentration of power of its administration (Rahman 2013). In this regard, excellent foreign ministry officers and diplomats have provided insightful recommendations and assist the foreign minister and his cabinet colleagues in order for Singapore to be able to discern future trends in the international political, security, and economic environment (Lee 2009). This allows Singapore to provide 'intellectual leadership' (Young 1991) in promoting new agendas and sustaining the benefits of an ASEAN Community.

At the ASEAN Informal Summit in 2000, Goh Chok Tong, the then prime minister of Singapore, launched the Initiative for ASEAN Integration (IAI) to help narrow the development gap among ASEAN member states (ASEAN Secretariat 2000). Although Singapore does not play the role of a 'regional paymaster', it has demonstrated a full commitment to reduce the apparent gap in the level of economic development among ASEAN members by utilising its strong economy. Singapore, under a five-year technical assistance programme of the IAI, offered several training institutes in Cambodia, Laos, Myanmar, and Vietnam, providing IT 'Train-the-Trainers' courses, for instance. Singapore also increased the number of existing Singaporean scholarships given to ASEAN nationals (ASEAN Secretariat 2000). In 2004, Singapore contributed an additional \$SGD28.9 million (\$US17.6 million) to support the implementation of the IAI as an important symbol of its commitment to foster closer economic integration and 
enhance ASEAN's competitiveness as a region (Singapore Cooperation Programme 2011). At the 13th ASEAN Summit in 2007, Singapore reaffirmed its continued commitment to the IAI by pledging another \$SGD30 million to cover technical assistance projects from 2009 to 2011 (ASEAN Secretariat 2007). At the 19th ASEAN Summit in Bali in November 2011, Singapore allocated a further contribution of \$SGD50 million from 2012 to 2015, bringing Singapore's total commitment to the IAI to S\$168.4 million (Singapore Cooperation Programme 2011). Singapore's contribution exceeds the other ASEAN member states' contribution in this regard. For example, in 2008, Singapore contributed approximately \$US84 million, while Thailand and Malaysia contributed approximately \$US12 million and \$US57 million, respectively (McGillivray and Carpenter 2013 , p. 145). In addition, Singapore is also a major contributor to numerous IAI projects in accordance with ASEAN Community Blueprint (see Table 4.1).

In May 2002, Singapore drove the ASEAN decision to commission a study of ASEAN's competitiveness in the face of growing competition from China and India and from other regional groups, such as the EU and North American Free Trade Agreement (NAFTA) (Severino 2006, p. 26). The study, which was undertaken by McKinsey \& Co, found that ASEAN had lost its competitive edge in terms of labour costs to China. Furthermore, China had overtaken ASEAN as the world's prime location for Foreign Direct Investments (FDIs) (Hew 2007 , p. 2). Following the report's findings, Singapore proposed an ASEAN Economic Community (AEC) as the next stage of ASEAN's regional economic integration. The proposal was adopted by the Summit in 2003 and incorporated in the Bali Concord II. Singapore

Table 4.1 IAI projects by funding by ASEAN-6 based on ASEAN Blueprint 2013

\begin{tabular}{lrrrrrc}
\hline Blueprints & Brunei & Indonesia & Malaysia & Philippines & Singapore & Thailand \\
\hline AEC & 2 & 10 & 10 & - & 38 & 2 \\
ASCC & 14 & 2 & 3 & 4 & 41 & 1 \\
APSC & - & 2 & 1 & - & 3 & - \\
General enabling & 2 & 1 & 4 & - & 44 & - \\
TOTAL & $\mathbf{1 8}$ & $\mathbf{1 5}$ & $\mathbf{1 8}$ & $\mathbf{4}$ & $\mathbf{1 2 6}$ & $\mathbf{3}$ \\
\hline
\end{tabular}

Source: Mekong Institute 2014, p. 7 
continues to play a leading role in promoting the economic integration of ASEAN. Singapore Prime Minister Lee Hsien Loong, in his speech at the 25th ASEAN Summit in Myanmar, expressed his optimism on the AEC and the benefits it will bring to the region when he stated that '[a]n ASEAN that is economically integrated, strong and united can better attract investments, create jobs, manage regional challenges, as well as be an effective platform to engage larger powers' (Loh 2014).

\subsubsection{Coalition Leadership}

As argued earlier in the chapter, coalition leadership is a part of a strategy for ASEAN member states to exert influence in ASEAN in order to sustain the benefits of a regional community without necessarily jeopardising its institutional norm-equality. Yeo Lay Hwee, during an interview, emphasised that 'I think leadership in ASEAN is still based on coalition, it can't be just one'. This is why Singapore actively builds coalition with other member states, especially Thailand, to exert influence in the region (Dent 2006). It has been able to convince Indonesia to assume a leading role in ASEAN (Priyambodo 2012). Of course, Singapore has developed bilateral relationships with other ASEAN member countries including the Cambodia, Laos, Myanmar, and Vietnam (CLMV) states, which are the beneficiaries of Singapore's capability-sharing programmes such as technology transfer programme (Wong et al. 2009, pp. 55-56). However, the Singapore-Thailand relationship is unique in the sense that the two states have been able to influence and determine the progress of ASEAN economic integration through, first, a shared vision on the establishment of an ASEAN Economic Community, and, second, through a convergence of economic interests.

With Thailand's support, Singapore was able to launch the AFTA in 1992. Singapore, aware of its small size and its advanced economy in comparison to that of its neighbours, decided to be not too aggressive in pushing the idea of AFTA. 'As we [Singapore] had a more advanced economy, open to the world and almost totally free of both tariff and non-tariff barriers, they [other ASEAN member states] feared that we would benefit disproportionately', said Lee Kuan Yew (2000, p. 382), the then senior minister. Lee Kuan Yew advised Prime Minister Goh in 1991 to ask Anand Panyarachun, the prime minister of Thailand, to take the lead in pushing for AFTA (Lee 2000, p. 383). Goh paid a visit to Prime Minister Anand 
in 1991, and the seed of AFTA was sown after that (Tang 1997). As expected, Anand (who had been a successful businessman and therefore understood the importance of an integrated economy and trade in the region in facing the challenges of globalisation and regionalism) took the leading role successfully (Lee 2000, p. 382). At the ASEAN Summit in Singapore in 1992, the member states agreed to establish AFTA by 2008 (this was later brought forward to 2003 by the ASEAN economic ministers).

The informal Singapore-Thailand coalition within ASEAN was not limited to trade. Singapore and Thailand summoned China to a health ministers' meeting on 26 April 2003 in Bangkok due to the outbreak of severe acute respiratory system (SARS) disease. This meeting was followed by a heads of government meeting on 28 April 2003 to establish a set of measures that each government would pledge to take to contain the spread of the disease (Breckon 2003, p. 74). Thailand government spokesman Sita Divari said, 'Goh Chok Tong telephoned the then Prime Minister of Thailand, Thaksin Shinawatra and proposed that ASEAN countries should meet to discuss the outbreak, because of its severe impact on the region and the world' (The Nation 2003). In this case, Singapore asked Bangkok to host the summit because Thailand had won praise for the preventive measures it had adopted against the deadly virus (The Nation 2003). Singapore's initiative in combating the SARS became 'the catalyst for intensified cooperation on health issues among ASEAN member countries' (Caballero-Anthony 2008, p. 517).

Apart from the Singapore-Thailand coalition leadership, Wong (2011) has stated that 'Indonesia and Singapore possibly can move ASEAN together'. The Singapore-Indonesia duo, according to Wong (2011), is crucial to providing strong leadership in ASEAN, especially with China's growing assertiveness, and the US looking to increase its presence in the Asian region. There are push factors from the outsidepredominantly emanating from the US-for both countries to play an even more active role in Asian regionalism. Indonesia is the 'pivotal' state for the US (Chase et al. 1996; Laksamana 2009), and Singapore is the key strategic alliance for the US in Southeast Asia (Acharya 2008, pp. 99-100). During his meeting with the then Indonesian President Susilo Bambang Yudhoyono in mid-2012, Singapore's Foreign Minister K. Shanmugam raised the need for Indonesia and Singapore to lead the push for the ASEAN member countries to negotiate and 
support a Code of Conduct (COC) $)^{4}$ on the long-running South China Sea dispute (Priyambodo 2012).

The Singapore-Indonesia coalition, however, suffers from what Wong called a 'divergence of interests' (Interview). Singapore has attempted to convince Indonesia of the benefits of having greater cooperation in the economic sphere since the 1970s. As Lee Kuan Yew (2000, p. 370) recalled, 'at bilateral meeting with Suharto in Bali in September in 1975, I tried to persuade him to agree to set economic targets for ASEAN at its first summit, which Indonesia should host'. However, Ali Mortopo, Suharto's close aide, later told K. C. Lee (then Singapore's ambassador) that after the meeting between Suharto and Lee Kuan Yew, Suharto's technocrats had advised him against free trade because of their fears that Indonesia would become a dumping ground for the goods of other ASEAN countries (Lee 2000, p. 370). Although Singapore remains very keen to promote an open and integrated regional economy, Indonesia remains rather reluctant to open its market. Hence, this helps explain the reliance on the Singapore-Thailand coalition for setting the pace of ASEAN economic integration rather than the Singapore-Indonesia coalition, where divergence of visions and interest between the two on this issue exists.

We now turn to the EU to examine the relationship between state capacity on the one hand, and leadership on the other.

\subsection{The EU Experience}

According to a definition advanced by Eckhard Lubkemeier, leadership in the EU is provided by actors who are willing and capable, acting as coleaders, to prompt other actors to contribute to the achievement of a collective goal (Schild 2010, p. 1369). The definition suggests that leadership in the EU emphasises the collective nature of leadership. It can neither be provided by a single actor, nor by the pursuit of narrow self-interested goals. The following section, therefore, examines the degree to which state capacity is crucial in the provision of political leadership within the

\footnotetext{
${ }^{4}$ In November 2002, ASEAN member states and China signed a non-binding political statement known as the Declaration on Conduct of Parties in the South China Sea (DOC). This document set out four trust- and confidence-building measures and five voluntary cooperative activities. The parties to the DOC reaffirmed 'that the adoption of a code of conduct in the South China Sea would further promote peace and stability in the region and agree to work, on the basis of consensus, towards the eventual attainment of this objective'. See, Point 10, Declaration on Conduct of Parties in the South China Sea, 4 November 2002.
} 
EU through an analysis of the Franco-German alliance. It also seeks to examine the limitations and opportunities for the EU's smaller member states-due to their relative lack of material resources-to influence agenda-setting and policymaking within the EU.

\subsubsection{Franco-German Alliance}

France and Germany, because of their size, economic influence, and political clout on one hand, and their mutual commitment to the project of European unity on the other, have been regarded as the 'motor of European integration' (Schild 2013, p. 25). Over the years, the alliance has shown its 'willingness' and 'capability' to set the pace of the EU, and to drive the European integration projects.

France and Germany were willing, and still are to some extent, to play leadership roles, as they both saw the economic and political benefits of integration. They believed that these benefits needed to be promoted even at the cost of frustrated national interests - a vision that is not entirely shared by other European countries such as Britain (Dedman 1996, p. 64; Janning 2005, p. 824). France, even though relatively weaker than Germany in terms of economic power, was, for a long time, a leading EU economy, only second to Germany. With Germany defeated, divided, and occupied, it was natural to assume a Franco-British coalition at the core of European integration (O'Donnell 2011; Valant and Curie 2012). However, France and the UK were in very different positions at the end of the Second World War. Britain showed a lack of enthusiasm for the idea of European integration given its political culture that emphasised national sovereignty, its history of only occasional direct involvement in continental European affairs, and its special wartime experience of having escaped invasion (Dinan 2010, p. 25). France, in contrast, opted for regional integration through reconciliation with its closest neighbour and biggest enemy, West Germany, for two main reasons. First, to avoid a repetition of the disastrous war, and, second, to sustain France's survivability and being able to co-exist with its closest neighbour-Germany (Dinan 2010, p. 25). The different positions between France and Britain at the end of the Second World War impeded the two countries in taking the lead of European integration.

It was the then French Foreign Minister Robert Schuman who proposed to place Franco-German production of coal and steel under one common supranational agency, the High Authority. According to the 
proposal, only through placing Germany's coal and steel under the control of a supranational agency would peace in the region be guaranteed, as the prospect of war between France and Germany would become materially impossible (Nugent 2010). For Germany, accepting the Schuman Plan and signing the Treaty of Paris in 1951 was the only way to commence West German national rehabilitation as an independent sovereign state, although the Treaty of Paris was arguably designed on French terms (Dedman 1996, p. 64). ${ }^{5}$ Participation in a supranational institution also allowed West Germany to regain legitimacy, to resume access to export markets, and to strengthen its impaired and weak state identity and economy (Paterson 2008, p. 92). French and German willingness to commit to the vision of European integration was manifested in the signing of the Treaty of Paris. Britain, in contrast, excluded itself from the discussions, leading to the European Coal and Steel Community (ECSC), as it was unwilling to sign prior to the start of negotiations, a communiqué with other governments agreeing in advance to the 'pooling of coal and steel production' and accepting the transfer of national control to a High Authority (Dedman 1996, p. 64).

Symbolism has always been an important feature of the mutual commitment in the Franco-German partnership. The Franco-German relationship has always been kept alive by symbols of unity. It commenced with de Gaulle and Adenauer's praying in Reims in 1963, Mitterrand and Kohl kneeling at the cemetery of Verdun in 1984, and the march of German troops at the Champs Elysee in July 1994. Their actions symbolised the extent of reconciliation, solidarity, and peace that had been achieved in the relationship (Cole 2008, p. 184). Declaring a symbolic and special diplomatic relationship remains a key concern of both countries. Angela Merkel's first foreign visit as chancellor to Paris in November 2005 and President François Hollande's visit to Berlin on the very day he became French president in May 2012, demonstrated the symbolic value of the historic and strategic ties between the two countries. On 22 January 2019, French President Emmanuel Macron and German Chancellor

\footnotetext{
${ }^{5}$ Politically, with the absence of Britain, France structured European integration in a manner that ensured a perpetual leading position for France. The High Authority, the supranational body of the ECSC, was designed and dominated by Jean Monnet. Economically, the ECSC did allow France to exert an element of control over German resources. Finally, the ECSC was important for France to regain global power after having lost its capacity to influence the global agenda following the Second World War and the increasing roles of the US and USSR in world politics (Paterson 2008, p. 92).
} 
Angela Merkel inked a 16-page Aachen Treaty as a symbol of their commitment to 'move ahead to ensure the security and wellbeing of citizens as well as a strong, sovereign and democratic Europe' (The Local 2019).

Central to the way in which the Franco-German core operated was the essence of what Stanley Hoffmann (1995) has called the EU's 'symmetry of the asymmetrical'. After Second World War, France was a 'political giant and economic dwarf', while Germany was an 'economic giant and political dwarf' (Guerot and Leonard 2011). Germany was (and remains) the biggest economy in the EU since the initiation of European integration. Indeed, in the first half of 2013, Germany reported a budget surplus of 16.1 billion euros (12.76 billion pounds) or 1.1 per cent of the GDP (The Wall Street Journal 2014). This provided advantage for Germany to exert influence on European integration together with France, which had political advantage at that time. Germany cooperated closely with France to push forward initiatives, finance the EU eastern enlargement, support small member states, strengthen the European Commission and the European Parliament (EP), and pay for compromises without demanding political representation to reflect its disproportionate financial contributions (Guerot 2003, pp. 46-47; Janning 2005, p. 829).

Cognisant of its economic capacity, Germany has been willing to fulfil the task of regional paymaster, a role that it is increasingly struggling with. In 2016 , for instance, Germany paid $€ 12.9$ billion more into the EU budget than it received back in EU funding (see Fig. 4.1). Germany is the biggest net contributor to the EU, followed by France, with Britain ranking third (Haas and Rubio 2017). With the Britain's decision to exit the Union, request for Germany to contribute more to the EU's budget is expressed publicly. For example, Günther Oettinger, European Union Budget Commissioner, requested Germany to contribute about $€ 3$ billion to 3.5 billion ( $\$ 3.76$ billion to 4.4 billion) more to the EU than it does now to help meet new challenges facing the Union (Reuters 2017). This is to cover the Britain's net contribution valued approximately $€ 9$ billion ( $\$ 10.12$ billion). In response to the demand, Germany has signalled its willingness to contribute more than it has in the past (Coalition Agreement 2018, p. 13). German Chancellor Angela Merkel of the Christian Democratic Union (CDU) and leader of the Social Democratic Party (SDP) Martin Schulz reinstated Germany's commitment to European integration as stated in their Coalition Agreement (2018, p. 13): 'We are prepared for Germany to make higher contributions to the EU budget. We want a budget that is clearly oriented towards future challenges with added value for Europe'. 


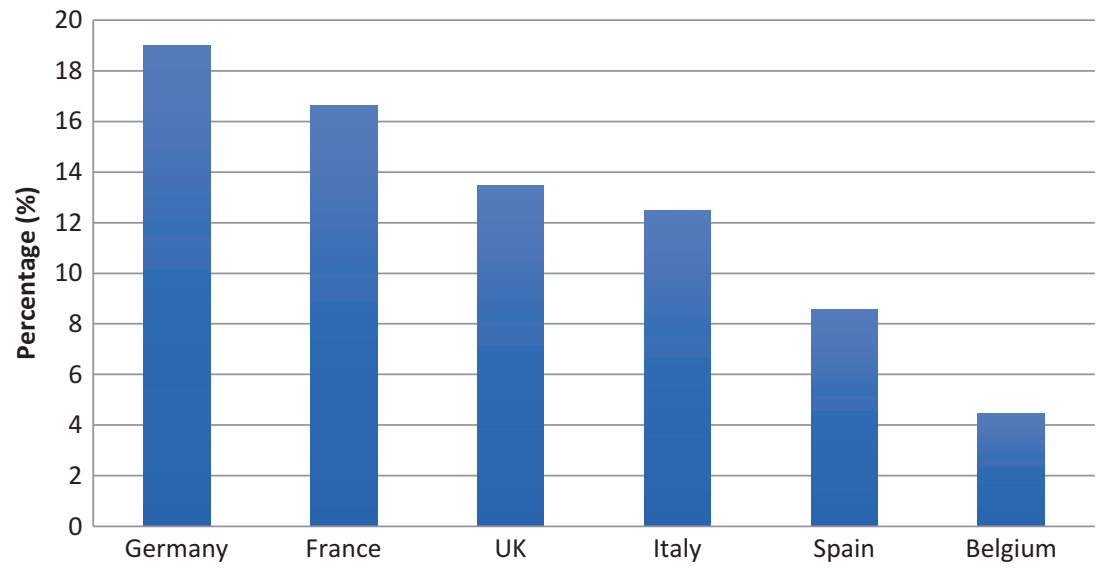

Fig. 4.1 Share of biggest contributors to the European Union budget in 2016. Source: https://www.statista.com/statistics/31669l/european-union-eu-budget-share-of-contributions/

Moreover, as the largest member states in the EU, both France and Germany have advantage in terms of structural power resources such as population size, military capabilities, political stability, and administrative capacity (Tallberg 2008, p. 687). France, as a proponent of the European integration process, and due to its size in administrative capacity and administrative legal culture, influences the 'administrative architecture' of the European institutions in a manner almost similar to the French administrative state system (Drake 2006, p. 92). The notions of the concours and the cabinets in the EU, for examples, are from France's influence (Drake 2006, p. 92). The term concours means a public contest or competition, and in the EU context, it refers to a recruitment competition and examination to select staff of all institutions of the EU. The term Cabinets literally means offices, and in the EU context, the term refers to a group of important advisors to a president, a minister, or a commissioner.

Furthermore, France and Germany exert more influence in EU decision-making bodies such as the Commission, the Council of Ministers, the European Parliament, and the Council Presidency (Bunse and Nicolaidis 2012, p. 251; Nugent 1999, pp. 427-424), or what Tallberg (2008, p. 694) has called 'institutional sources of power' as another source for state capacity. Although the establishment of both the supranational and intergovernmental institutions was seen as a means to guarantee a fair 
balance between big and small states (Bunse and Nicolaidis 2012, p. 251), in some institutions such as the Commission and the Council of the EU, a larger state often, although not always the case, has more leverage to influence the decision-making processes of the EU. Nugent (1999, p. 472) argues that there are many channels in which the government can try to persuade, influence, or bring pressure to the Commission. In so doing, the government can utilise 'formal channels such as the group of experts who advise the Commission on all sorts of matters, the management and regulatory committees through which the Commission exercises many of its executive functions, and the numerous decision-making meetings that take place within the Council system from working party levels upwardmeetings which the Commission always attends' (Nugent 1999, p. 472). The utilisation of these channels, however, depends upon the domestic policies, administrative capacity, as well as the qualities of the diplomats, officials, and negotiators of a particular government. Also, well-staffed administrative infrastructure with expertise, clear responsibilities, and coordination procedures, which are enjoyed by larger states such as France and Germany, allows these countries to produce effective bargaining, especially at supranational level of the EU's institution such as the European Commission (Kutys 2009, p. 7). Further, larger member states have the financial capacity to engage in additional negotiation strategies and therefore to be overall more active than smaller member-states. This gives advantage to large member states such as France and Germany, as they are able to draw on their financial strength and large administrative machinery when preparing proposals, developing and offering EU training, and creating expert groups.

The Council is designed to represent national interests and to make joint decisions with the European Parliament (EP) (Lewis 2012, p. 321). Its main task is to decide-in conjunction with the EP-which proposals for new European laws and policies will be adopted and which will not (McCormick 2011, p. 194). In this regard, where a vote is needed, the larger member states, especially France and Germany, are always likely to carry more voting weightage than smaller countries such as Portugal and Luxembourg (McCormick 2011, p. 195). Under this Qualified Majority Vote (QMV) arrangement, 'each member state representative has a certain number of votes, as set out in the EU treaties. The weighting votes roughly reflect the size of population of each member states' (Consilium 2015) (see Table 4.2). What's more, from 1 November 2014, a QMV will require a double majority to adopt proposals: decisions in the Council will need 
Table 4.2 Qualified majority voting in the Council of Ministers 2015

\begin{tabular}{lrlrll}
\hline Germany & 29 & Belgium & 12 & Lithuania & 7 \\
UK & 29 & Hungary & 12 & Latvia & 4 \\
France & 29 & Portugal & 12 & Slovenia & 4 \\
Italy & 29 & Austria & 10 & Estonia & 4 \\
Spain & 27 & Bulgaria & 10 & Cyprus & 4 \\
Poland & 27 & Sweden & 10 & Luxemburg & 4 \\
Romania & 14 & Slovakia & 7 & Malta & 3 \\
The Netherlands & 13 & Denmark & 7 & & \\
Greece & 12 & Finland & 7 & & 345 \\
Czech Republic & 12 & Ireland & 7 & Total & \\
\hline
\end{tabular}

Source: Author's own compilation based on http://www.consilium.europa.eu/en/council-eu/votingsystem/qualified-majority/

the support of 55 per cent of member states, and these member states at the same time represent 65 per cent of the EU population (Article 9(c) Treaty of Lisbon). The new system of QMV focuses on the demographic weightage of the member states. Therefore, the strength of the three largest member states of the EU-France and Germany along with Italy-in the shaping of agenda, brokering compromises, and building coalition either to support or blocking particular agenda is reinforced (Poptcheva and Devaney 2014) (Fig. 4.2).

While material resources give the Franco-German alliance an advantage in exercising their joint-leadership role in the EU, it has been their mutual commitment to the project of European unity, particularly in finding compromises and in forging agreements, that makes their leadership significant. France and Germany have reiterated to significantly intensify cooperation in the area of EU foreign policy, as reflected with the signing of the Aachen Treaty on 22 January 2019. With the signing of the treaty, German Chancellor Angela Merkel, and her counterpart, French President Emmanuel Macron, declared their commitment to 'give an impulse to European unity' and 'to continue to build it with force and determination' (Chazan 2019).

There have been a few occasions where the absence of a strong FrancoGerman mutual commitment has slowed the progress of the EU regional integration project. For example, throughout the 1990s, there were some serious divisions between France and Germany. The 1992 Maastricht Treaty almost failed to be ratified due to the French public's dissatisfaction with European integration (Wunderlich 2007, p. 98). 


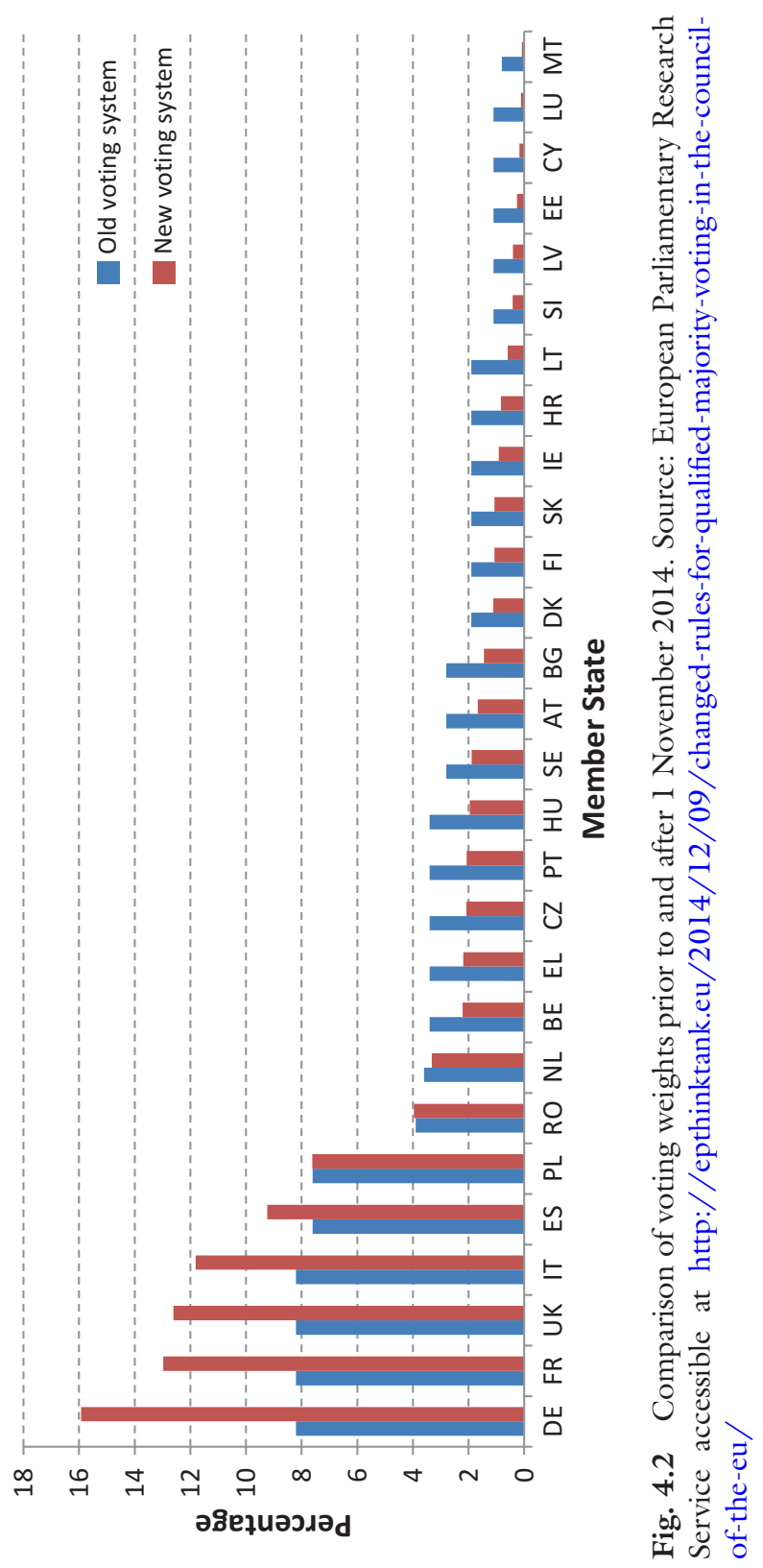


Moreover, France became a difficult partner with regard to the 2004 eastern enlargement-a project that France viewed as a German goal, and for which it was not willing to commit (Cole 2008, p. 152). There were also disagreements on the reform of the Common Agricultural Policy (CAP), budgetary provisions, the General Agreement on Tariffs and Trade (GATT) Uruguay round, and structural funds, among others (Cole 2008, p. 154). It was during the Treaty of Nice in 2000 that the Franco-German tandem was shaken to the core (Cole 2008; Janning 2005). This marked the first time when there was no joint letter preceding the Summit. The basis for this was the different positions that France and Germany had on the role of the Council. Germany requested more votes in the Council to take into consideration its larger population. France and other member states, including the UK, rejected the request based on the grounds that Germany had already received more seats in the European Parliament in 1992 to compensate for its larger population (Cole 2008, p. 154). These instances demonstrate that without strong Franco-German mutual commitment, the development of the EU and the process of regional community-building are weakened.

The leadership of the Franco-German partnership has also been challenged by the divisions on how to manage the third Greek bailout and refugee crisis. In late June 2015, Athens submitted a revised reform plan to the EU and International Monetary Fund (IMF). This was because Greece's previous arrangement with European Financial Stability Facility (EFSF), namely, the Greek Master Financial Assistance Agreement (MFAA), expired on 30 June 2015-the very same day that Greece defaulted on a $\$ 1.7$ billion IMF repayment (de Finance et al. 2015). France and Germany, however, had divergent views on whether or not Greece was entitled to a third bailout. Germany demanded stringent reform and austerity measures from Athens, while France was supportive of Greece's request for further aid. The diverging views meant that a compromise between the Eurozone leaders, France and Germany, was hard to achieve, and therefore had the potential to lead to the break-up of European Monetary Union, the EU's most ambitious project (Taylor 2015). After long and tough negotiations, including the threat from European leaders together with the European Commission of the likelihood of the withdrawal of the Greek from the Eurozone, Donald Tusk, the Chair of the Euro Summit and President of the European Council, announced on 12 July 2015 that "[l] eaders have agreed in principle that they are ready to start negotiations on an ESM [European Stability 
Mechanism] programme, which in other words means continued support for Greece' (cited in General Secretariat of the Council 2015). Thanks to Merkel's assertiveness and her firm stance, Greece was allowed to negotiate a new deal to prevent its exit (Grexit) from the Euro-a recommendation that was also supported by her former Finance Minister Wolfgang Schäuble. As Merkel believed that the so-called Grexit might undermine the entire currency union, she stated that ' $[\mathrm{w}] \mathrm{e}$ would be grossly negligent, and act irresponsibly, if we didn't at least attempt this way [to negotiate with Greece]' (cited in $A B C 2015$ ).

France and Germany have also opted for different approaches in dealing with the refugee crisis when thousands of refugees from war-torn countries such as Syria fled to European borders in the summer of 2015. While Germany has taken the lead from the very beginning of the crisis, insisting that the refugees be allowed to stay in Germany and apply for asylum-seeker status, France, with other member states such as the UK and Hungary, has been reluctant to open its border to the refugees flooding into the EU across the Mediterranean and Balkans. As a result, Europe has struggled to respond to worsening migrant crisis (Tessa 2015). After months of debate and discussion, Merkel and the then French President François Hollande made a joint address to the European Parliament on 7 October 2015, where they together pleaded for more cooperation among EU states in addressing the refugee crisis engulfing the continent. According to Merkel (2015), 'the opportunities [of more Europe] are greater than the risks' (cited in EurActiv 2015).

The Franco-German leadership, therefore, remains influential (mainly due to their mutual commitment to the EU project), but is no longer as dominant as it once was. There are two reasons to explain this shift. First is the uneven nature of the alliance. Second, there is a growing divergence in approaches to respond to prevailing challenges as aforementioned issues. One of the main reasons for this is related to France's weakening economy, and, in comparison, to Germany's economy. While Germany continues to hold more bargaining chips due to its larger economic and more robust finances, the French economy is weakening. France's current debt, deficit and growth, and lack of a clear strategy under both Sarkozy and Hollande, undermine its capacity for European (joint) leadership (Clift and Ryner 2014, p. 150; Matthijs 2016, p. 137). This has changed the dynamics between France, which once was perceived to lead in political terms, and Germany, which was stronger in the economic sphere, which worked as a stabilising feature of the duo (The Economist 2013). 
Nevertheless, the ongoing commitment of the two countries, especially in managing the Eurozone and refugees' crises, although both countries used divergent approaches to deal with them, proves that the FrancoGerman tandem remains essential in driving European integration during the crisis.

\subsubsection{Smaller States in the EU: Punching Above Their Weight}

We have discussed that the 'willingness' and 'capability' of the FrancoGerman alliance to exert more influence through agenda-setting and decision-making procedures has led them to be regarded as the 'engine of Europe'. Clearly, the tangible and intangible national resources of France and Germany have given them the advantage to play leadership roles in the EU. Smaller member states, in contrast, do not have the budgetary or personnel resources that are available to larger states (Nugent 2006, pp. 58-59). Furthermore, they do not have the resources to cover all policy areas under EU competence-from agriculture to fishing, from working directives to food colouring and food preparation-and therefore have to decide on priority areas (Archer and Nugent 2006, p. 4). Yet, in some specific areas, it can be argued that smaller states can be the 'policymakers', providing a degree of leadership and producing important policy outputs.

It is therefore worth mentioning the case of the Nordic member states (in particular, Sweden, Denmark, and Finland) who have been 'punching above their weight' in some specific policy areas. In doing so, these states have provided greater leadership roles through the Presidency of the Council (Tallberg 2008; Della Sala 2012). It is during their Presidency of the Council that these states dedicated more time and resources to enable them to provide effective leadership roles (Della Sala 2012, p. 314). For example, the 2001 Swedish Presidency of the Council was seen by other EU member states as an example of strong presidency, as Sweden provided a degree of leadership and produced important policy outputs, particularly with regard to the introduction of conflict prevention in the Common Foreign and Security Policy (CFSP) (Della Sala 2012, p. 314).

Although the introduction of the European Council President under the Treaty of Lisbon marginalises the importance of the rotating presidency, in which the Presidency of the Council is now chaired by a 'permanent' president and the Foreign Affairs Council is headed by a permanent chair, the High Representative for Foreign Affairs and Security Policy 
(Article 9b, Treaty of Lisbon), the rotating presidency remains a matter for EU policymaking (Batory and Puetter 2013, p. 96). As argued by Batory and Puetter (2013, p. 96), "the functional rationale for the rotating Presidency in providing effective and legitimate governance to the overall EU system of decision-making remains strong'. The revised rotating presidency provides small states a good opportunity to gain influence, since the issues left to the rotating presidency are 'low politics' issues, whereby all individual small states have a realistic change of influence during their presidency and the 'high politics' issues are now taken over by the new Council President and the High Representative for Foreign Affairs and Security Policy (Howard-Gron and Wivel 2011, p. 533).

As the rotating President of the Council Ministers in the second half of 2010, Belgium, in the face of the dramatic loss of relevance of the Council's Presidency leadership function, decided to emphasise the role as facilitator, ensuring the effective transition towards post-Lisbon having the ability to act, for instance, in foreign affairs by helping to establish the European External Action Service (EEAS) - the new EU foreign ministry (Van Hecke and Bursens 2011, p. 5). The then Belgium's Foreign Minister, Steven Vanackere, speaking just before the end of the presidency on 20 December, asserted Belgium's commitment to ensure that the 'four wheels' of the EU institutions (European Council, EU Commission, EP, and EU's foreign policy chief) 'moved at the same speed and in the right direction' (Taylor 2011). In so doing, Belgium invested substantially in a good working relationship with the European Commission and European President by utilising the trialogues - the informal negotiations between the Council of Ministers, represented by the rotating president, the EU Commission, and the EP (Van Hecke and Bursens 2011, p. 5). This shows that the rotating presidency is significant for the small state in facilitating the agenda-shaping of the EU as a mediator and facilitator for the issues related to collective good problems such as capacity-building, and implementation of the adopted EU policies and strategies.

The formation of coalitions is another strategy, which smaller states have used to influence EU decision-making, both at pre- and post-Lisbon. In the EU, there are shifting coalitions among member states, depending on the issues. In this setting, it is important to take into account that all member states are equal, but some are more important than others (Rood 2009 , p. 67). This applies in particular to the big member states, specifically France and Germany, whose support is crucial for the formation of a winning coalition (Rood 2009, p. 68). Furthermore, the success of the coalition depends on the issue around which the coalition is formed. The 
Netherlands, for example, has devoted time and effort to champion efforts to influence economic and monetary union (Maes and Verdun 2005). The Netherlands, as a trading nation with a very open and outward-looking economy, has always been a supporter of European economic integration ( Rood 2009, p. 68). It has close working relations with the Commission, the EU's bigger member states (France, German, and the UK), and member states that have taken a leading role in economic cooperation such as Belgium (Maes and Verdun 2005, p. 342). The Netherlands was an important ally of Germany in its push for ensuring that macro-economic integration was well developed before moving towards deeper monetary integration (Maes and Verdun 2005, p. 330). The Netherlands collaborated with Belgium in the area of monetary policymaking, and contributed to the European integration process, although their strategies differed $^{6}$ (Maes and Verdun 2005, p. 343). The Netherlands, in the 1970s and the 1980s, played the role of a 'gate-keeper' in seeking consensus, especially between the Dutch and the British, with more restrictive view on the conditions under which EMU was possible (Maes and Verdun 2005 , p. 344). Likewise, once the EMU was accepted, the Netherlands was firm on the interpretation of the criteria for entry, which can be seen in its attitude to the inclusion of countries such as Italy in the third stage of EMU (Maes and Verdun 2005, p. 26). This shows that coalitions based on the specific issues represent an alternative strategy for smaller member states to punch above their weight.

\subsection{Conclusion and Comparative Comments}

This chapter has shown that state capacity is crucial in order to play leadership roles in a regional context, both in ASEAN and the EU, in order to maintain the benefits of regional community-building through agendasetting, policy implementation, and policy continuation. The main finding of this chapter suggests that state capacity is a product of tangible and intangible resources of the member states, as well as their access to institutional power resources such as the ASEAN Summit for ASEAN, the European Commission, and the Council for the EU.

\footnotetext{
${ }^{6}$ Belgium was a close ally of the European Commission, and one of its constant concerns was to have EMU on the agenda. The Netherlands, in contrast, preferred pushing for economic coordination prior to further monetary integration (see Maes and Verdun 2005, p. 25).
} 
Economic strength does matter in this sense, as demonstrated by Germany's role as a regional paymaster in the EU. There is no such regional paymaster in ASEAN, as member states' contribution is based on 'equal annual contributions, which shall be remitted in a timely manner' (Article 30(2) ASEAN Charter 2008). As a result, the implementation of the agreed ASEAN initiatives has been hampered by its limited budget, as implementation requires substantial amount of funding (Julio Amador III 2011). However, Singapore has been willing to support and fund some of ASEAN's initiatives such as the IAI to foster closer economic integration and enhance ASEAN competitiveness.

A country's size gives it an advantage in exerting influence in regional community-building, particularly in ASEAN, although ASEAN regards all of its members as equal. In this sense, Indonesia, due to its size, has been regarded as the de facto leader in ASEAN. This was evident even before the establishment of ASEAN. ASEAN member states opted to support Indonesia's proposal for a new regional organisation in Southeast Asia region, rather than rejuvenate the ASA, because they felt that it was crucial to have Indonesia as a member for regional cooperation in Southeast Asia. Nevertheless, Indonesia's role as the de facto leader of ASEAN has been questioned in recent years due to its reticence to play an effective leadership role, especially in the area that ASEAN needs leadership most at the moment-economic integration.

In the EU, the role of its two largest countries-France and Germanyhas been regarded as the tandem or engine for driving European integration even though they have not always been on good terms. Together, they led the formation of the ECSC, the predecessor of the EU, and since then had been key agenda-setters in the EU, determining the pace of European integration. Without their mutual commitment to the European integration project, the EU's key agenda items such as the 1992 Maastricht Treaty, the CAP, budgetary reform, and enlargement would not have been achieved (Cole 2008, p. 27). Over the years, the Franco-German alliance has been strengthened and reaffirmed through symbolism, summit meetings between the president and the chancellor, and meetings among their national leaders and elite.

Such an alliance is not evident in the ASEAN case. However, there are sectoral leaderships and coalition leaderships among ASEAN members that have influenced the development of ASEAN's regional communitybuilding efforts. In this regard, Singapore has been an active coalitionbuilder, seeking to form coalitions with other member states such as 
Thailand and Indonesia in search of more influence in ASEAN agendasetting. With regard to sectoral leadership, Singapore has been the champion of ASEAN economic integration, along with Malaysia and Thailand, while Indonesia has led in security and political integration. This chapter found that sectoral leadership and coalition leadership are strategies, which ASEAN member states use to play more influential roles in ASEAN through maximising their state resources. Likewise, such coalition leadership is also evident in the EU. It is a strategy that smaller member states such as the Nordic and Benelux countries have used to influence the policymaking of the EU. Due to their relative size, a coalition with other states enables these member states to punch above their weight within the EU. Nevertheless, the findings of this research suggest that the main reason for ASEAN and EU member states to exert influence on specific issues is not primarily to maintain the benefits of regional integration. Rather, their active roles are driven by the necessity to protect their national interests.

Institutional power resources also constitute sources of state capacity in leadership roles. ASEAN has very few resources in this regard because of its heavy emphasis on intergovernmental cooperation. As such, ASEAN does not have supranational power resources, but the ASEAN Summit has been utilised by ASEAN member states for setting the agenda of ASEAN for at least the year in which they hold the Chairmanship. Chapter 6 will further examine ASEAN Summit and leadership in ASEAN. Likewise, institutional power resources of the EU such as the Commission, the Council, and the Presidency of the Council provide advantage for its members to exert increased influence. This is particularly evident when a state holds the Presidency of the Council. In this sense, the Presidency can exercise influence by contributing its own preferences to the agenda, attributing varying weights to agenda items, and keeping certain issues away from the agenda.

The important point that this chapter makes is that there is a correlation between state capacity and the function of leadership in ASEAN and the EU contexts. In this regard, major initiatives and agenda-settings are promoted and decided by the member states that are capable of doing so. Nevertheless, this chapter has also found that state capacity is necessary, but not a sufficient condition for playing a leadership role, both in ASEAN and the EU. Indeed, it is mainly based on the mutual commitment of the Franco-German alliance in the EU, and Indonesia, Singapore, and Thailand in ASEAN, that the benefits of the EU and ASEAN regional community-building can be maintained by maximising their state capacity. Additionally, this conclusion is also influenced by Britain's reticence to 
promote the European regional project, despite its advantage in terms of its economic size (Guerot 2003). In 2013, Britain had considered leaving the Union (Cameron 2013). On 23 June 2016, Britain opted to exit the Union. Similarly, there has been an expectation from a number of ASEAN leaders, including Singapore's former Prime Minister Goh Chok Tong, that due to Indonesia's size, it should play a more assertive leadership role in the AEC. Indonesia, however, has considered not supporting the AEC if its economic interests are threatened (Parameswaran 2014; Kosasih 2015). Ultimately, the functions of leadership can only be demonstrated if the member states are willing to marshal their state capacity to support regional community-building projects.

The main findings of this chapter lead to a number of questions, which require answers in order to further comprehend leadership issues in regional community-building efforts in this book. First, under what conditions has the Franco-German alliance been accepted as the 'engine' or motor for European integration? What is the basis for the acceptance of their leadership by other member states? Why is Indonesia recognised as the de facto leader in ASEAN? Under what conditions has Indonesia been, and might be, expected by other member states to play a more assertive leadership roles in ASEAN? The following chapter will address these questions by examining the degree to which legitimacy is crucial as the basis for leadership role in ASEAN and the EU.

\section{REFERENCES}

ABC. 2015. Greek Debt Crisis: Germany's Parliament Backs Greece Bailout Negotiations Despite Rebellion, July 18. http://www.abc.net.au/news/201507-18/german-parliament-backs-greek-bailout-talks-despite-rebellion/6629950. Accessed 14 Oct 2015.

Acharya, A. 2008. Singapore's Foreign Policy: The Search for Regional Order. Hackensack, NJ: Institute of Policy Studies/World Scientific.

Amador, J.D., III. 2011. Official ASEAN and Southeast Asia Desk. Philippines: Foreign Service Institute. In-Depth Personal Interview.

Anderson, M., B. Andrew, M.-T. Magui, and B. Marie. 2005. Measuring Capacity and Willingness for Poverty Reduction in Fragile States. Working paper, Department for International Development's Policy Division, UK. http:// www.cgu.edu/include/spe/SPE04.pdf. Accessed 13 Mar 2012.

Antolik, M. 1990. ASEAN and the Diplomacy of Accommodation. New York \& London: An East Gate Book.

Anwar, D.F. 1994. Indonesia in ASEAN: Foreign Policy and Regionalism. Singapore: Institute of Southeast Asian Studies. 
1997. ASEAN and Indonesia: Some Reflections. Asian Journal of Political Science 5: 20-34.

- 2006. Leadership in the History of Southeast Asia Integration: The Role of Indonesia in ASEAN. In Regional Integration in East Asia and Europe: Convergence or Divergence, ed. B. Fort and D. Webber, 59-68. London and New York: Routledge.

Archer, C., and N. Nugent. 2006. Introduction: Does the Size of Member States Matter in the European Union? Journal of European Integration 28 (1): 3-6.

ASEAN Charter. 2008. ASEAN Charter. ASEAN Secretariat, Jakarta. http://www. asean.org/archive/publications/ASEAN-Charter.pdf. Accessed 13 Jan 2012.

ASEAN Secretariat. 2000. The Fourth ASEAN Informal Summit 22-25 November 2000. http://www.asean.org/news/item/the-fourth-asean-informal-summit22-25-november-2000-singapore. Accessed 23 Jan 2013.

- 2007. Chairman's Statement of the 13th ASEAN Summit. One ASEAN at the Heart of Dynamic Asia, Singapore, 20 November. Accessed 23 Jan 2013.

Batory, A., and U. Puetter. 2013. Consistency and Diversity? The EU's Rotating Trio Council Presidency After the Lisbon Treaty. Journal of European Public Policy 20 (1): 95-112.

Berita Harian. 1966. Bukan untok masoki ASA: Adam Malik (Not for Joining ASA: Adam Malik), May 1. http://eresources.nlb.gov.sg/newspapers/ Digitised/Article/beritaharian 19660501-1.2.3.aspx?q=Thanat + Khoman+ ASA\&page $=3 \&$ sort $=$ relevance $\&$ token $=a s a \% 2$ ckhoman $\% 2$ cthanat $\&$ sessionid $=9$ 85d5c8c3fe746e2afl leb0fba5331ef. Accessed 14 Oct 2015.

Breckon, L. 2003. China-Southeast Asia Relations: SARS and a New Security Initiative from China. Comparative Connections 5 (2): 73-82.

Bunse, S. 2009. Small States and EU Governance: Leadership Through the Council Presidency. Basingstoke: Palgrave Macmillan.

Bunse, S., and K.A. Nicolaidis. 2012. Larger Versus Small States: Anti-hegemony and the Politics of Shared Leadership. In The Oxford Handbook of the European Union, ed. E. Jones, A. Menon, and S. Weatherill, 249-266. Oxford: Oxford University Press.

Caballero-Anthony, M. 2005. Regional Security in Southeast Asia: Beyond the ASEAN Way. Singapore: Institute of Southeast Asian Studies Publications.

- 2008. Non-traditional Security and Infectious Diseases in ASEAN: Going Beyond the Rhetoric of Securitization to Deeper Institutionalization. The Pacific Review 21 (4): 507-525.

Cameron, D. 2013. Speech at Bloomberg: Prime Minister David Cameron Discussed the Future of the European Union at Bloomberg, January 23. https://www.gov. uk/government/speeches/eu-speech-at-bloomberg. Accessed 13 Apr 2014.

Camroux, D. 2006. The Rise and Decline of the Asia-Europe Meeting (ASEM): Asymmetric Bilateralism and the Limitations of Interregionalism. Les Cabiers europeens de Sciences Po, no. 4. http://www.cee.sciences-po.fr/erpa/docs/ wp_2004_6.pdf. Accessed 14 June 2013. 
Chase, R., E. Hill, and P. Kennedy. 1996. Pivotal States and U.S. Strategy. Foreign Affairs January/February: 33-51.

Chazan, G. 2019. Macron and Merkel Sign Aachen Treaty to Deepen FrancoGerman Ties. Financial Times, January 22. https://www.ft.com/content/ fecf3854-1e37-11e9-b2f7-97e4dbd3580d. Accessed 20 Feb 2019.

Chowdhury, A. 2007. Indonesia's Hesitance with AFTA and AFTA Plus: A Political Economy Explanation. Paper presented at the FTA, Regional Integration, and Development, Pusan National University, Busan, Korea, December 18-19.

Clift, B., and M. Ryner. 2014. Joined at the Hip, but Pulling Apart? FrancoGerman Relations, the Eurozone Crisis and the Politics of Austerity. French Politics 12 (2): 136-163.

Coalition Agreement. 2018. Coalition Agreement Between CDU, CSU and SPD 19th Parliamentary Term, Konrad Adenauer Stiftung, March 5. https://www. kas.de/c/document_library/get_file? uuid=bd4lf012-1a71-9129-81708189ald06757\&groupId=284153. Accessed 12 Jan 2019.

Cole, A. 2008. Franco-German Relations: From Active to Reactive Cooperation. In Leaderless Europe, ed. J. Hayward, 147-166. Oxford: Oxford University Press.

Consilium. 2015. Qualified Majority 'A New Rule from l November 2014', January 5. http://www.consilium.europa.eu/en/council-eu/voting-system/ qualified-majority/. Accessed 5 Apr 2015.

Dedman, M.J. 1996. The Origins and Development of the European Union 1945-95. London and New York: Routledge.

Della Sala, V. 2012. Leaders and Followers: Leadership Amongst Member States in a Differentiated Europe. In The Oxford Handbook of the European Union, ed. E. Jones, A. Menon, and S. Weatherill, 306-321. Oxford: Oxford University Press.

Dent, C.M. 2006. The New Economic Bilateralism and Southeast Asia: RegionConvergent or Region-Divergent. International Relations of the Asia-Pacific $6(1): 81-111$.

Dinan, D. 2010. Ever Closer Union: An Introduction to European Integration. 4th ed. Basingstoke: Palgrave Macmillan.

Djani, D.T. 2009. A Long Journey. In The Making of the ASEAN Charter, ed. T.T.B. Koh, R.G. Manalo, and W. Woon, 137-150. Singapore: World Scientific Publishing.

Drake, H. 2006. France: An EU Founder Member Cut Down to Size. Journal of European Integration 28 (1): 89-105.

Emmers, R. 2011. Academic at S. Rajaratnam School of International Studies (RSIS), Nanyang Technology University, Singapore. In-depth Personal Interview.

- 2014. Indonesia's Role in ASEAN: A Case of Incomplete and Sectorial Leadership. The Pacific Review 27 (4): 543-562. 
2015. Academic at S. Rajaratnam School of International Studies (RSIS), Nanyang Technology University, Singapore. In-depth Personal Interview.

EurActiv. 2015. Ministers Reject Commission's Immigrant Quota Proposal, 17 June. Accessed 14 Jan 2016.

Fawcett, L. 2005. Regionalism from an Historical Perspective. In Global Politics of Regionalism: Theory and Practice, ed. M. Farrell, B. Hettne, and V.L. Langenhove, 21-37. London: Pluto Press.

- 2013. The History and Concept of Regionalism. UNU - CRIS, Bruges. http://cris.unu.edu/sites/cris.unu.edu/files/W-2013-5.pdf. Accessed 14 Jan 2014 .

- 2015. Drivers of Regional Integration: Historical and Comparative Perspectives. In Drivers of Integration and Regionalism in Europe and Asia: Comparative Perspectives, ed. L. Brennan and P. Murray, 34-51. Hoboken: Taylor and Francis.

de Finance, S., J.V. Broucke, and R. Drachenberg. 2015. Extraordinary European Council Meeting on Greece, 12 July 2015, European Parliamentary Research Service, July 11. http://epthinktank.eu/2015/07/11/12-july-extraordinaryeuropean-council-meeting-on-greece/. Accessed 14 Oct 2015.

Genna, G., and T. Hiroi. 2007. Brazilian Regional Power in the Development of Mercosul. Latin American Perspectives 34 (5): 43-57.

Guerot, U. 2003. France and Germany: The Evolution of a European Partnership. Paper presented at the Conference on Regional Integration in Europe and Asia: Past, Presents, and Futures, Singapore, July 7-8.

Guerot, U., and M. Leonard. 2011. The New German Question: How Europe Can Get the Germany Needs. Policy Brief 30/2011, European Council on Foreign Relations (ECFR), London. http://www.ecfr.eu/page/-/ECFR30_ GERMANY_AW.pdf. Accessed 14 Mar 2013.

Haas, J., and E. Rubio. 2017. Brexit and the EU Budget: Threat or Opportunity. Policy Paper, No. 183, January 16. Paris: Notre Europe/Institut Jacques Delors. http://www.institutdelors.eu/media/brexiteubudget-haasrubio-jdijanl7.pdf?pdf $=$ ok.

Hayward, J. 2008. Introduction: Inhibited Consensual Leadership Within an Interdependent Confederal Europe. In Leaderless Europe, ed. J. Hayward, 1-11. Oxford: Oxford University Press.

Hecke, V., and P. Bursens. 2011. Analysing Post-Lisbon Rotating Presidency: Lessons from the Belgian Case. Preliminary Paper for the conference The Commanding Heights of the European Union. The European Council: Institutions, Actors and Resources, Brussels, March 10-11. http://steunpuntbov.be/rapport/Bursens_VanHecke_2011_VUB.pdf. Accessed 14 Jan 2016.

Hendrix, C.S. 2010. Measuring State Capacity: Theoretical and Empirical Implications for the Study of Civil Conflict. Journal of Peace Research 47 (3): 273-285. 
Hernandez, C. 2011. Chairman and Founder Institute of Strategic and Development Studies, Philippines. In-depth Personal Interview.

Hew, D. 2007. Introduction: Brick by brick - The Building of an ASEAN Economic Community. In Brick by Brick - The Building of an ASEAN Economic Community, ed. D. Hew, 1-12. Singapore: Institute of Southeast Asian Studies.

Hoffmann, S. 1995. The European Sisyphus: Essays on Europe, 1964-1994. Colorado: Westview Press.

Howard-Gron, C., and A. Wivel. 2011. Maximizing Influence in the European Union After the Lisbon Treaty: From Small State Policy to Smart State Strategy. Journal of European Integration 33 (5): 523-539.

Janning, J. 2005. Leadership Coalitions and Change: The Role of States in the European Union. International Affairs 81 (4): 821-833.

Kosasih, F.U. 2015. Indonesian and ASEAN: Where Are We Going? Global Indonesian Voices, July 30. http://www.globalindonesianvoices.com/21846/ indonesia-and-asean-where-are-we-going/. Accessed 5 Oct 2015.

Kutys, P. 2009. Small States Inside the EU: Strategies for Pursuing Their National Interests. Tiltai 47 (4): 1-12.

Laksamana, E.A. 2009. Indonesia's Pivotal Role in the US's Grand Strategy. The Jakarta Post, October 6. http://www.thejakartapost.com/news/2009/10/ 06/indonesia\%E2\%80\%99s-pivotal-role-us\%E2\%80\%99s-grand-strategy.html. Accessed 13 Feb 2013.

- 2011. Indonesia's Rising Regional and Global Profile: Does Size Really Matter? Contemporary Southeast Asia 33 (2): 157-182.

Lee, K.Y. 2000. From Third World to First: The Singapore Story, 1965-2000. New York: HarperCollins Publishers.

Lee, P.P. 2006. Small States in the European Community and ASEAN in Asian Regional Groupings Compared. In The Emerging East Asian Community: Security and Economic Issues, ed. P.P. Lee, T. Siew Yan, and G.T. Yu, 125-144. Bangi: Penerbit Universiti Kebangsaan Malaysia.

Lee, K.Y. 2009. The Fundamentals of Singapore Foreign Policy: Then and Now. Rajaratnam Lecturer, April 9. http://www.news.gov.sg/puublic/sgpc/en/ media_release/agencies/pmo/speech/s-20090409-/html. Accessed 24 Jan 2014.

Leifer, M. 1989. ASEAN and the Security of Southeast Asia. London: Routledge.

Lewis, J. 2012. Council of Ministers and European Council. In The Oxford Handbook of the European Union, ed. E. Jones, A. Menon, and S. Weatherill, 321-335. Oxford: Oxford University Press.

Loh, D. 2014. ASEAN Must Respond in Decisive, Coordinated Way to Regional Issues: PM Lee. Channel News Asia, 12 November. http://www.todayonline. $\mathrm{com} /$ singapore/asean-must-respond-decisive-coordinated-way-regional-issues-pm-lee. 
Lukito, P. 2012. Leadership Key to Indonesian Bureaucratic Reform. The Jakarta Post, 15 February, Opinion. http://www.thejakartapost.com/news/2012/02/ 15/leadership-key-indonesian-bureaucratic-reform.html-sthash.LGro3yVc.dpuf.

Maes, I., and A. Verdun. 2005. Small States and the Creation of EMU: Belgium and the Netherlands. Journal of Common Market Studies 43 (2): 393-412.

Matthijs, M. 2016. The Three Faces of German Leadership. Survival 58 (2): 135-154.

Mattli, W. 1999a. Explaining Regional Outcomes. Journal of European Public Policy 6 (1): 1-27.

- 1999b. The Logic of Regional Integration: Europe and Beyond. Cambridge: Cambridge University Press.

Mcbeth, J. 1977. Thanat Looks Back. Asiaweek, 5 August, p. 14.

McCormick, J. 2011. European Union Politics. New York: Palgrave Macmillan.

McGillivray, M., and D. Carpenter. 2013. Narrowing Development Gap in ASEAN: Drivers and Policy Options. Hoboken: Taylor and Francis.

Mekong Institute. 2014. Mid-term Review of the Implementation of the IAI Work Plan II for Equitable Economic Development and Narrowing the Development Gap, vol. 2: Technical Annexes, 28 March, Khoen Kaen University, Thailand. http://aadcp2.org/file/IAIMTRTechnicalAnnexes.pdf. Accessed 14 Oct 2015.

Merkel, A. 2015. More Migrant Talks Needed, Merkel Says. Reuters, news clip, 26 June. http://www.nytimes.com/video/world/europe/100000003765764/ more-migrant-talks-needed-merkel-says.html. Accessed 14 Jan 2016.

Mien, C.T. 1996. Foreign Ministry Wants 20-30 Mid-Career Officers. The Straits Times, April 24. p. 22. http://eresources.nlb.gov.sg/newspapers/digitised/ issue/straitstimes19960424-1\#. Accessed 23 Mar 2015.

Murphy, A.M. 2002. From Conflict to Cooperation in Southeast Asia, 1961-1967: The Disputes Arising Out of the Creation of Malaysia and the Establishment of the Association of Southeast Asia. PhD thesis, Colombia University.

Narjoko, D.A. 2014. Why Indonesia Needs to Lead in Economic Integration. East Asia Forum, March 3. http://www.eastasiaforum.org/2014/03/03/whyindonesia-needs-to-lead-in-economic-integration/. Accessed 13 June 2014.

Nugent, N. 1999. The Government and Politics of the European Union. Basingstoke: Macmillan Press Ltd.

- 2006. Cyprus and the European Union: The Significance of Its Smallness, Both as an Applicant and a Member. Journal of European Integration 28 (1): $51-71$.

. 2010. The Government and Politics of the European Union. 7th ed. New York: Palgrave Macmillan.

Nye, J.S. 2004. Soft Power: The Means to Success in World Politics. New York: Public Affairs. 
2009. Understanding International Conflicts. 7th ed. New York: Pearson.

O'Donnell, C.M. 2011. Britain and France Should Not Give Up on EU Defence Co-operation. Centre for European Reform London, London. http://www. cer.org.uk/sites/default/files/publications/attachments/pdf/2011/pb_ csdp_24oct1 1-3907.pdf. Accessed 13 June 2013.

Parameswaran, P. 2014. Is Indonesia Turning Away from ASEAN Under Jokowi? The Diplomat, December 18. http://thediplomat.com/2014/12/is-indonesia-turning-away-from-asean-under-jokowi/. Accessed 22 December 2014.

Parlina, I. 2015. Jokowi Expedites Replacement of High-Ranking Officials. The Jakarta Post, March 14. http://www.thejakartapost.com/news/2015/ 03/14/jokowi-expedites-replacement-high-ranking-officials.html. Accessed 16 April 2015.

Paterson, W.E. 2008. Did France and Germany Lead Europe? A Retrospect. In Leaderless Europe, ed. J. Hayward, 89-112. Oxford: Oxford University Press.

Phanit, T. 1980. Regional Integration Attempts in Southeast Asia: A Study of ASEAN's Problems and Progress. PhD thesis, Pennsylvania State University, Pennsylvania.

Poptcheva, E., and C. Devaney. 2014. Changed Rules for Qualified Major Voting in the Council of the EU, European Parliamentary Research Service, December 9. http://epthinktank.eu/2014/12/09/changed-rules-for-qualified-majority-voting-in-the-council-of-the-eu/. Accessed 14 Jan 2016.

Prasojo, E. 2012. Accelerating Bureaucratic Reform. Jakarta Post, June 5. http:// www.thejakartapost.com/news/2012/06/05/accelerating-bureaucraticreform.html. Accessed 14 Aug 2014.

Priyambodo, R. 2012. Indonesia, Singapore Agree to Safeguard Stability in ASEAN Region. Antara News, October 25. http://www.antaranews.com/ en/news/85220/indonesia-singapore-agree-to-safeguard-stability-in-aseanregion. Accessed 21 Mar 2013.

Rahman, M.A. 2013. Singapore: The Best Bureaucracy in Asia. The Financial Express, September 14. http://print.thefinancialexpress-bd.com/old/index. php?ref=MjBfMDlfMTRfMTNfMV85OV8xODMzMzc $=$. Accessed 14 Oct 2015.

Rattanasevee, P. 2014. Leadership in ASEAN: The Role of Indonesia Reconsidered. Asian Journal of Political Science 22 (2): 113-127.

Rau, R.L. 1981. The Role of Singapore in ASEAN. Contemporary Southeast Asia 3 (2): 99-112.

Reuters. 2017. Brexit Means Germany Will Have to Pay More Into EU Budget Oettinger, February 28. https://uk.reuters.com/article/uk-britain-eu-budget-germany-idUKKBN16626K. Accessed 23 Jan 2019.

Robles, A.C. 2007. The Asia-Europe Meeting: The Theory and Practice of Interregionalism. London: Routledge. 
Rood, J. 2009. The Netherlands as an EU Member State: A Middle-Sized Country in Search of Its European Destiny, Clingandael Institute, the Hague. http:// www.clingendael.nl/sites/default/files/20091200_directie_artikel_rood.pdf. Accessed 13 Mar 2015.

Schild, J. 2010. Mission Impossible? The Potential for Franco-German Leadership in the Enlarged Europe. Journal of Common Market Studies 48 (5): 1367-1390.

- 2013. Leadership in Hard Times. German Politics and Society 31 (1): 24-47.

Severino, C.R. 2004. Will There Be a New ASEAN in the 21st Century? AsiaEurope Journal 2 (2): 179-184.

- 2006. Southeast Asia in Search of an ASEAN Community: Insights from the Former ASEAN Secretary-General. Singapore: Institute of Southeast Asian Studies.

Singapore Cooperation Programme. 2011. Initiative for ASEAN Integration. http://www.scp.gov.sg/content/scp/iai_programmes/about.html. Accessed 13 Jan 2013.

Smith, A. 1999. Indonesia's Role in ASEAN: The End of Leadership? Contemporary Southeast Asia 21 (2): 238-260.

Tallberg, J. 2008. Bargaining Power in the European Council. Journal of Common Market Studies 46 (3): 685-708.

Tang, E. 1997. Thai PM Will Be Among Old Friends. The Straits Times (Singapore), 31 March 2015.

Taylor, S. 2011. A New Role Under Lisbon. Europe Voice, January 6. http:// www.politico.eu/article/a-new-role-under-lisbon/. Accessed 14 Jan 2016.

Taylor, P. 2015. In Greek Crisis, One Big Unhappy EU Family. Reuters, July 19. http://mobile.reuters.com/article/iduskcn0pt05w20150719? irpc $=932$. Accessed 14 Oct 2015.

Tessa, B. 2015. Europe Struggles to Respond to Worsening Migrant Crisis. The Time, September 11. http://time.com/4021383/europe-reacts-migrant-crisis/. Accessed 12 Oct 2015.

The Economist. 2013. France and Germany: A Tandem in Trouble, May 4. http://www.economist.com/news/europe/21577100-european-union-fretting-over-widening-gulf-between-two-partners-have-always. Accessed 4 Feb 2015.

The Local. 2019. 'We Want to Move Ahead': Macron and Merkel to Sign New Franco-German Treaty, January 9. https://www.thelocal.fr/20190109/ macron-and-merkel-to-sign-new-franco-german-treaty. Accessed 23 Feb 2019.

The Nation. 2003. Singapore-Thailand Cooperation: SARS, April 18. http:// www.asiantribune.com/news/2003/04/18/rare-asean-meeting-bangkokhost-summit-sars. Accessed 24 Mar 2015.

The Straits Times. 1966. Reviving ASA, 27 May. Accessed 14 Oct 2015. 
1967a. Agreed - It's ASEAN, August 8. http://eresources.nlb.gov.sg/ newspapers/Digitised/Page/straitstimes19670808-1.1.l.aspx. Accessed 30 Aug 2015.

_ 1967b. Down to Earth Plan Call by Malik, September 17. http://eresources.nlb.gov.sg/newspapers/Digitised/Article/straitstimes196709171.2.17.aspx. Accessed 30 Aug 2015.

The Wall Street Journal. 2014. Germany's Budget Surplus Strengthens Hand in Dealing with Vulnerable Eurozone Economies, February 7. http://blogs.wsj. com/economics/2015/02/24/germanys-budget-surplus-strengthens-handin-dealing-with-vulnerable-eurozone-economies/. Accessed 14 Mar 2015.

Thorhallsson, B. 2006. The Size of States in the European Union: Theoretical and Conceptual Perspectives. Journal of European Integration 28 (1): 7-31.

United Nations. 1991. Agreements on a Comprehensive Political Settlement of the Cambodia Conflict, Department of Public Information. http://www.usip. org/sites/default/files/file/resources/collections/peace_agreements/final_ act_10231991.pdf. Accessed 14 Mar 2014.

Valant, P., and M. Curie. 2012. The Franco-German Couple: Potentials and Limitation. Paper presented at the THESEUS Conference, Brussels, December 6-7. http://theseus.uni-koeln.de/fileadmin/Background_Paper_FrancoGerman-couple-Potential-and-limits. Accessed 21 Feb 2013.

Wanandi, J. 2008. The ASEAN Charter and Remodeling Regional Architecture. The Jakarta Post, November 3. http://www.thejakartapost.com/ news $/ 2008 / 11 / 03 /$ insight-the-asean-charter-and-remodeling-regionalarchitecture.html. Accessed 14 Jan 2013.

Webber, D. 2010. The Regional Integration That Didn't Happen: Cooperation Without Integration in Early Twenty-First Century East Asia. The Pacific Review 23 (3): 313-333.

Wong, R. 2011. Academic, National University of Singapore. In-depth Personal Interview.

Wong, J., T.K. Song, Y. Mu, S. Tong, L.T. Seng, and L.C. Kia. 2009. A Study on Singapore's Experience in Regional Cooperation Report. Hong Kong: East Asian Institute of National University of Singapore.

Wunderlich, J.-U. 2007. Regionalism, Globalisation and International Order: Europe and Southeast Asia. Hampshire: Ashgate Publishing Limited.

Young, O. 1991. Political Leadership and Regime Formation: On the Development of Institutions in International Society. International Organization 45 (3): 281-307.

Zwartjes, M., V. Langenhove, S. Kingah, and L. Maes. 2012. Determinants of Regional Leadership: Is the European Union Leading Regional Actor in Peace and Security. Southeast European and Black Sea Studies 12 (3): 393-405. 